\title{
Pattern of varicella and associated complications in children in United Arab Emirates: 5-year descriptive study
}

S.A. Uduman, ${ }^{1}$ M. Sheek-Hussein, ${ }^{2}$ M. Bakir, ${ }^{3}$ O. Trad, ${ }^{4}$ M. Al-Hussani, ${ }^{2}$ J. Uduman ${ }^{2}$ and F. Sheikh ${ }^{5}$

$$
\text { ساينا أو دو مانحاق، وحمد شيخ المضاعفات التي تصاحبه أطفال الإمارات العربية المتحدة: دراسة وصمود بكير، عمر طر اد، موسى الحوسني، ج. أودمان، فاروق شيت } 5 \text { سنوات }
$$

الخلاصسة: كان الغرض من هذه الدراسة توصيف السمات الوبائية للحاق وللمضاعفات التي تصاحبه في إمارة

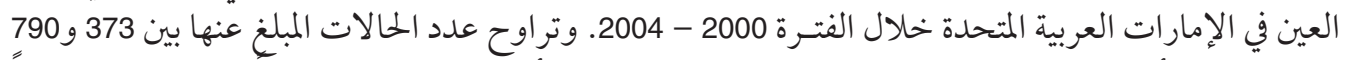

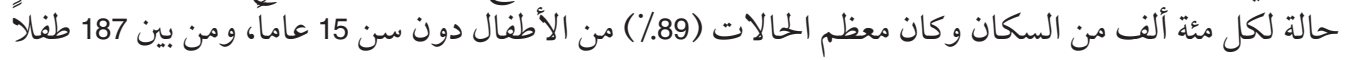

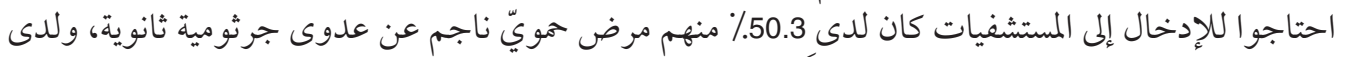

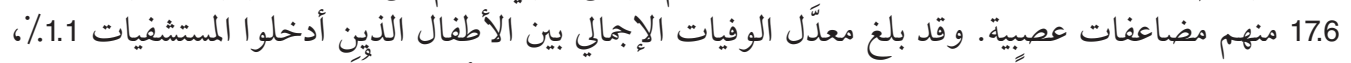

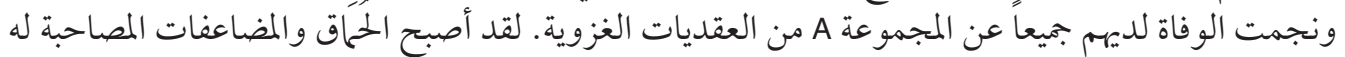

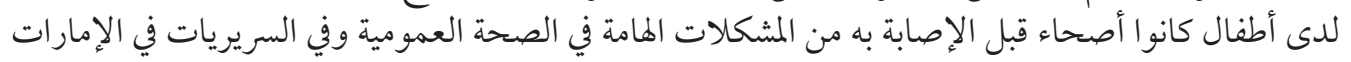
العربية المتحدة.

ABSTRACT The objective of this study was to characterize the epidemiology of varicella and varicellaassociated complications in Al-Ain, United Arab Emirates (UAE) during 2000-04. The annual number of reported cases varied from 373 to 790 per 100000 population. Most $(89 \%)$ occurred in children $<15$ years old. Of 187 children requiring hospital admission, $50.3 \%$ had febrile illness due to secondary bacterial infection and $17.6 \%$ had neurological complications. The overall mortality rate among hospitalized children was $1.1 \%$, all due to invasive group A Streptococcus. Varicella and associated complications in previously healthy children is becoming an important clinical and public health problem in the UAE.

Évolution de la varicelle et des complications associées chez l'enfant aux Émirats arabes unis : étude descriptive sur 5 ans

RÉSUMÉ L'objectif de cette étude était de caractériser l'épidémiologie de la varicelle et des complications associées à cette maladie à Al-Ain, aux Émirats arabes unis (ÉAU), entre 2000 et 2004. Le nombre annuel de cas déclarés variait de 373 à 790 pour 100000 habitants. La plupart des cas (89\%) se comptaient parmi les enfants âgés de moins de 15 ans. Sur 187 enfants nécessitant une hospitalisation, 50,3\% présentaient un syndrome fébrile dû à des infections bactériennes secondaires et $17,6 \%$, souffraient de complications neurologiques. Le taux de mortalité global chez les enfants hospitalisés était de $1,1 \%$, dans tous les cas à cause d'infections invasives à streptocoque du groupe A. La varicelle et les complications associées chez des enfants jusque-là en bonne santé sont en passe de devenir un problème clinique et de santé publique important aux ÉAU.

${ }^{1}$ Department of Paediatrics, Faculty of Medicine and Health Sciences, United Arab Emirates University, AlAin, United Arab Emirates (Correspondence to S.A. Uduman: udumans@uaeu.ac.ae).

${ }^{2}$ Department of Preventive Medicine; ${ }^{3}$ Department of Paediatrics, General Authority for Health Services, Al-Ain, United Arab Emirates.

${ }^{4}$ Department of Paediatrics, Tawam Hospital, Al-Ain, United Arab Emirates.

${ }^{5}$ Microbiology Section, Al-Ain Hospital, Al-Ain, United Arab Emirates.

Received: 16/11/06; accepted: 16/04/07

المجلة الصحية لشرق المتوسط، منظمة الصحة العالمية، المجلد الخامس عشر، العدد ع، 9 + • 


\section{Introduction}

Varicella (chickenpox) is now a vaccinepreventable disease and has been included in the infant immunization schedule in many parts of the world [1,2]. Globally, this has led to an increased awareness of the importance of varicella and its epidemiology, immunology and clinical impact on the community [3-5]. To our knowledge the health impact of childhood varicella in the population of the United Arab Emirates (UAE) has not been quantified and the reported data on varicella-associated morbidity and mortality are limited [5-7]. Varicella is a reportable disease in the UAE and generally viewed as a self-limiting illness in healthy children. This study was carried out before the availability of varicella vaccine for UAE children. It aimed to map the background epidemiology of varicella over 5 years and record the clinical data of hospitalized children.

Al-Ain city is a traditional oasis, inland desert region with an estimated population of 475000 [8]. The climate ranges between a relatively cool, dry winter and a hot, dry summer with minimal yearly rainfall. AlAin and Tawam hospitals are tertiary care centres providing health care services both for UAE citizens and for the multinational expatriate population residing in the region.

\section{Methods}

The varicella seasonality, disease incidences and age specificity were estimated from the varicella notifications compiled by the Department of Preventive Medicine at AlAin General Authority for Health Services [9]. All the notified cases were clinically diagnosed and reported by primary care clinic physicians.

Varicella-associated complications were derived from an established hospital-based surveillance system and from the medical records of patients admitted to the general paediatric wards in Al-Ain and Tawam hospitals, teaching hospitals affiliated to the United Arab Emirates University. Data gathered from medical records included information about age, sex, nationality, reason for admission, type of complication, duration of hospitalization and disease outcome. A complication associated with varicella illness was defined as a condition or event occurring within 3 weeks of onset of skin rash.

Statistical analysis was carried out using Student $t$-test for comparison of continuous variables, confirmed by nonparametric Mann-Whitney $U$-test. Chi-squared analysis was performed to test for differences in proportions of categorical variables between $\geq 2$ groups. In $2 \times 2$ tables, the Fisher exact test (2-tailed) was used when sample size was small. Chi-squared goodness-of-fit test was used for trend. $P<0.05$ was considered as the cut-off value for significance.

\section{Results}

\section{Incidence of varicella}

The number of cases of varicella reported over the 5 consecutive years ranged from 1754 to 3712 cases each year, giving an annual incidence of 373-790 per 100000 population. The monthly distribution and the seasonal wave of varicella cases are shown in Figure 1. There was a statistically significant difference $(P<0.0001)$ in the monthly rate of cases reported during the 5 -year study period (with a strong peak during March-May). A higher proportion of the reported varicella cases were in males than females (58\% versus $42 \%)$ and $80 \%$ were among UAE nationals.

A majority of cases (89\%) occurred in children aged $<15$ years. Age-specific

المجلة الصحية لشرق المتوسط، منظمة الصحة العالمية، المجلد الخامس عشر، العدد ع، 9 +. ب 


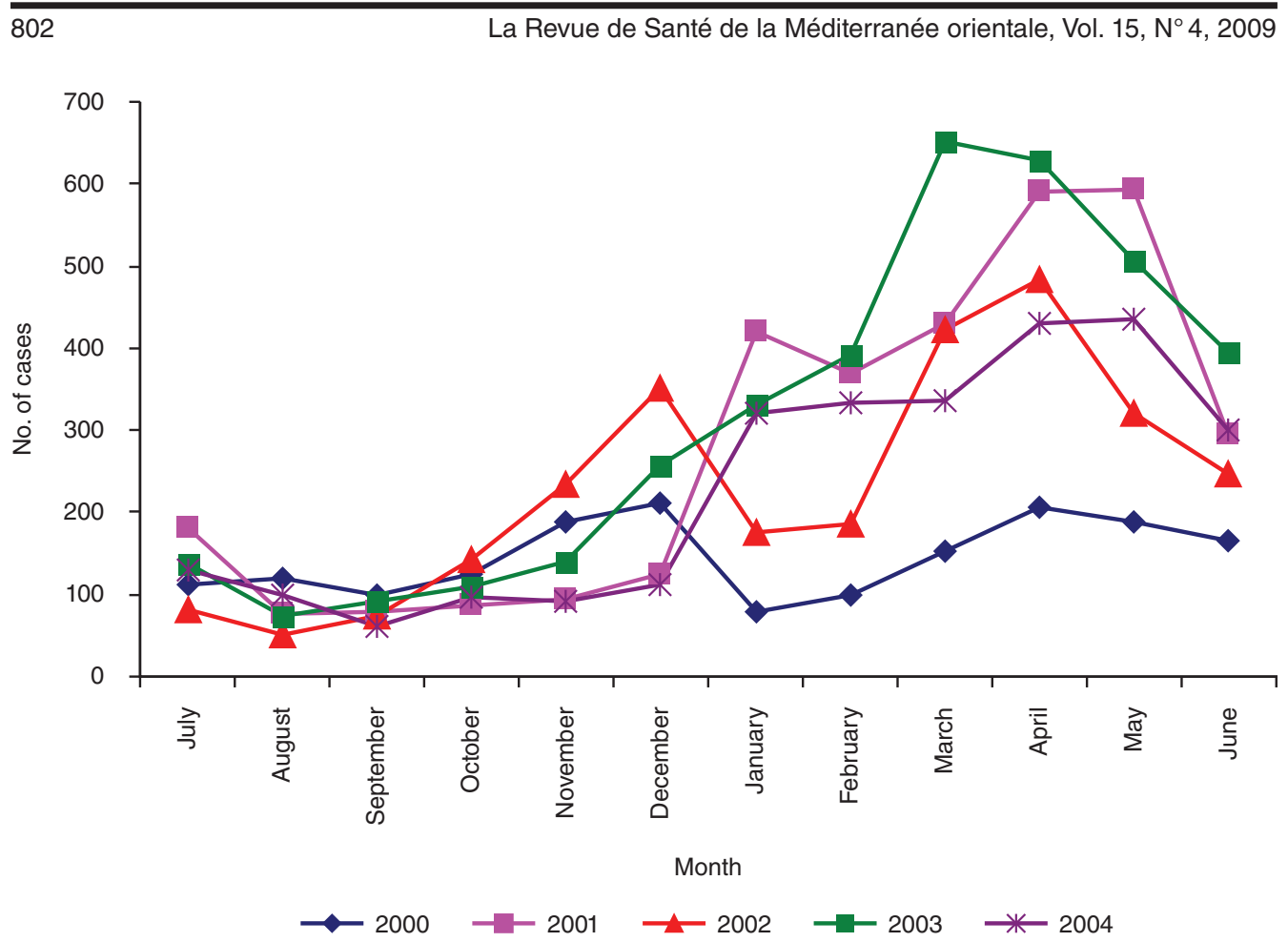

Figure 1 Monthly distribution of reported varicella cases in the United Arab Emirates, 2000-04

incidence was derived from population estimates of the Emirates Ministry of Health $[8]$. Over the 5 years, $2 \%$ of cases were in infants $<1$ year old, $37 \%$ of cases occurred in preschool children aged 1-5 years (estimated annual incidence 129 per 1000 children) and 50\% occurred in school-age children aged $6-15$ years ( 89 per 1000 children). A history of recent household contact with siblings attending school was recorded in $>40 \%$ of varicella-infected children $<5$ years of age.

\section{Varicella-associated complications}

Of the 187 children admitted to hospital 136 $(72.7 \%)$ were $<5$ years of age, including 10 neonates $(22.5 \%$ aged $0-1$ year and $50.3 \%$ aged $1-5$ years), $25.0 \%$ were $6-10$ years and $2.7 \%$ were $11-15$ years. Mean age was 5.9 years. Length of hospital stay averaged 7.5 days. The number of admissions increased during the peak seasons of the year.

Table 1 records varicella-related illness among the hospitalized children, all of whom were reported to be healthy before contracting varicella. Bacterial infection was the reason in 94 cases (50.3\%): secondary bacterial infection of the skin or soft tissue (47 cases, $25.1 \%$ ) and respiratory tract infection, including clinical pneumonia, (45 cases, $24.1 \%$ ) were the most common complications. Children with soft-tissue infections were younger than children with other complications. Group A Streptococcus and Staphylococcus aureus were the most common organisms identified. Two children died of group A Streptococcus septicaemia associated with soft tissue in-

المجلة الصحية لشرق المتوسط، منظمة الصحة العالمية، المجلد الخامس عشر، العلد ع، 9 +. 


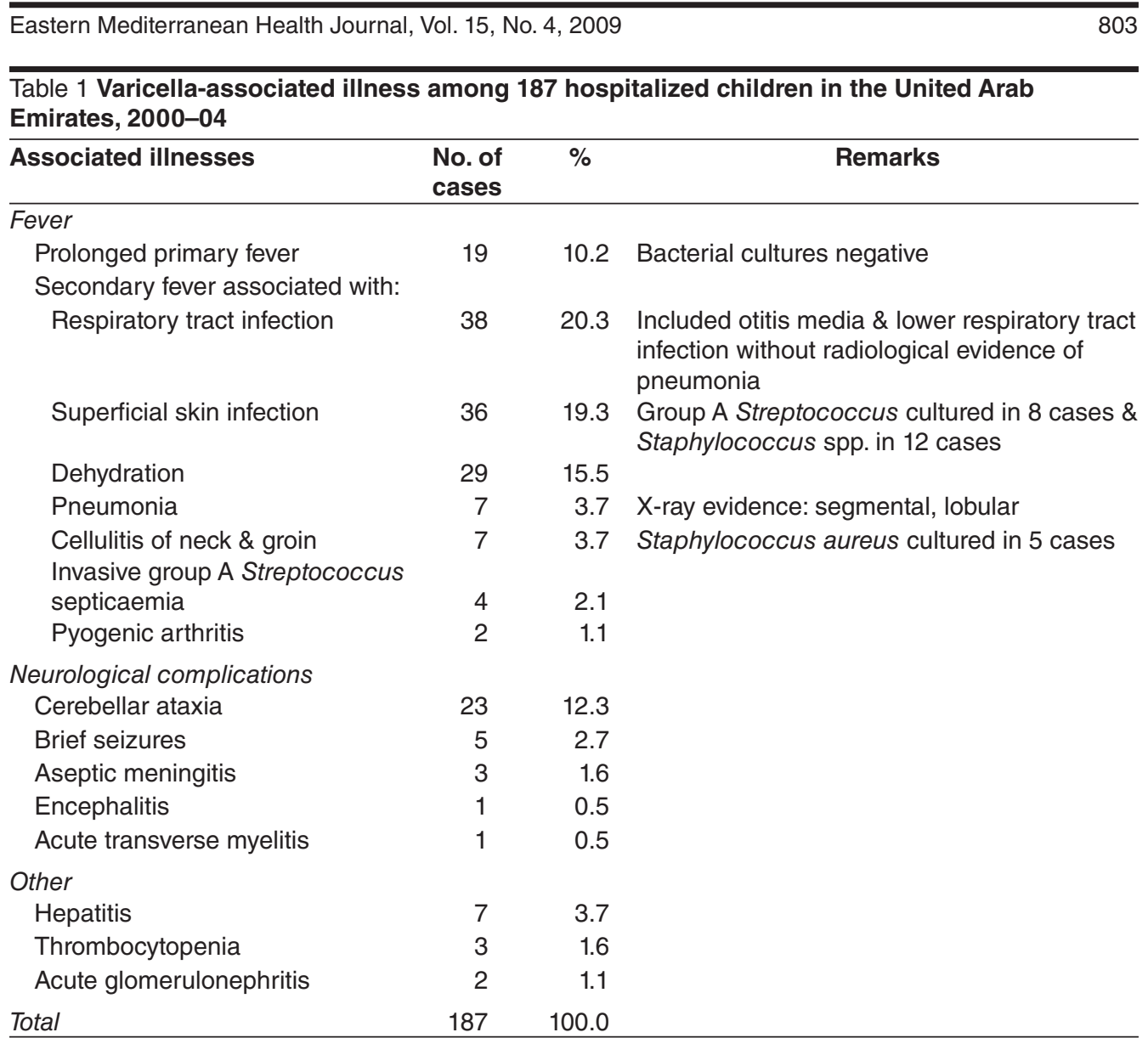

fection, representing an overall case fatality rate among hospitalized children of $1.1 \%$.

There were $33(17.6 \%)$ children admitted to hospital with neurological signs and symptoms (Table 1); 23 (mean age 6.2 years) presented with acute cerebellar ataxia 6-17 days (mean 8 days) after the onset of rash. Five febrile children (median age 1.9 years) presented with single brief seizures with no other associated neurological manifestations.

\section{Discussion}

Varicella is generally thought to be a benign disease and the systemic symptoms are usu- ally mild in previously healthy children. In contrast, in adults varicella is frequently associated with complications and death, and the infection is known to be severe, progressive and often fatal among immunocompromised individuals, including neonates and children $[10,11]$.

The UAE is a newly developed country with a divergent, multinational, working adult population in a desert climate. The epidemiology of varicella followed the pattern typical in temperate climates with infection acquired at an earlier age. It supports our own earlier study in the region that children of school-age lacked immunity against varicella [5]. The age susceptibility

المجلة الصحية لشرق المتو سط، منظمة الصحة العالمية، المجلد الخامس عشر، العدد ع، 9 +. 
to varicella zoster virus has regional and geographical variations $[12,13]$.

There are no other varicella incidence figures or hospitalization data from the UAE for comparison. Infectious complications occurred mostly in children aged $<5$ years, in agreement with earlier studies from the United States of America (USA) Canada and many European countries [12-14]. Over $60 \%$ of cases in the USA occur in children age 5-9 years, with $80 \%$ under 10 years of age $[15,16]$. In a recent study from Canada, the age groups $1-4$ years and 5-9 years represented close to $80 \%$ of the annual cases of varicella, as in our study where $70 \%$ of cases were $1-10$ years old [11].

There have been many reports in recent decades of varicella causing severe illness and occasionally fatalities in healthy children [17-19]. In industrialized countries, varicella caused more deaths and hospitalizations in previously healthy persons without underlying immunocompromising conditions $[20,21]$. We identified 187 children requiring hospitalization for varicella-associated complications during the 5-year observation period. Of these, $72.7 \%$ were aged $<5$ years, including 10 neonates. Perinatally-acquired varicella infections were mild because of the passive immunoprophylaxis therapy administered after the mother's exposure to Varicella virus. Neonatal varicella can be serious, and without these drugs mortality rates may be as high as $31 \%[10,22]$.

Bacterial skin superinfections were the largest cause of complications in our hospitalized children, a finding that is consistent with previous epidemiological studies $[18,19,21]$. Recent reports warn of an increase in hospitalization for secondary bacterial infection, notably those caused by invasive group A Streptococcus. We cultured group A Streptococcus associated with soft tissue infection in 4 children,
2 of whom died. Suspicion of secondary bacterial infection should prompt early recognition when fever returns after initial defervescence. Considering the virulent nature of superinfection, especially with Staphylococcus and group A Streptococcus in varicella-infected children, it is prudent to institute empirical antimicrobial therapy in selected cases until the cultures become available.

CNS involvement was the second commonest complication, seen in $17.6 \%$ of hospitalized children, but no mortality was recorded. This rate of CNS complications was significantly higher than the $6 \%$ reported in Canada, but much lower than the $61 \%$ reported in previously healthy children in Germany $[17,19]$. Symptoms of postinfectious cerebellar ataxia appeared late in the course of varicella infection, as described in other reported studies. All the children recovered spontaneously and residual cerebellar syndrome persisted for 4 and 7 months in 2 cases. Five other children presented with brief febrile convulsions without other neurological abnormalities at the onset of varicella rash, presumably precipitated by the onset of fever. Long-term neurological outcomes and disability associate with varicella are often not reported, which hampers comparison.

To our knowledge this is the first reliable data published from the UAE on varicella. The study provides an insight into varicellarelated clinical issues among previously healthy children in the region. While mortality from varicella is relatively rare for healthy children, the exact economic burden pertinent to childhood varicella morbidity is unknown in our health care context. Nationwide surveillance is needed to estimate the health and financial impact of varicella in our population while considering the introduction of varicella vaccine into the Expanded Programme on Immunization

المجلة الصحية لشرق المتوسط، منظمة الصحة العالمية، المجلد الخامس عشر، العلد ع، 9 + • 
in the UAE. Until then, varicella-related complications, hospitalization and death attributable to chickenpox will continue to occur among our children and nonimmune adult populations.

\section{Acknowledgements}

This work was funded partially by the Department of Paediatrics, Faculty of Medicine and Health Sciences, and UAE University.

We wish to thank the public health staff of the Department of Preventive Medicine,
Al-Ain and the Ministry of Health for providing the age and nationality specific varicella data at short notice. We thank the medical and nursing staff of Al-Ain and Tawam hospitals for their invaluable enthusiasm for this investigation. We are particularly grateful to Mohamed Uduman, Rochester Institute of Technology, New York, USA, for his continued help in collating data for our varicella surveillance activities from the year of 2000 . Also we thank our departmental secretary, Rose Clemente, for her assistance in preparing the manuscript.

\section{References}

1. Epidemiology and prevention of vaccinepreventable diseases. Atlanta, Georgia, Centers for Disease Control and Prevention, 2002.

2. Rentier B, Gershon AA, European Working Group on Varicella. Consensus: varicella vaccination of healthy children-a challenge for Europe. Pediatric infectious disease journal, 2004, 23(5):379-89.

3. Weller TH. Varicella zoster virus: history perspectives and evolving concerns $\mathrm{Neu}$ rology, 1995, 45(8):S9-10.

4. Decline in annual incidence of varicellaselected states, 1990-2001. Morbidity and mortality weekly report, 2003, 52(37):884-5.

5. Uduman SA et al. Clinical and epidemiological aspects of varicella-zoster virus infections in Al-Ain, United Arab Emirates. In: Proceedings of the 3rd International Conference on the Varicella-Zoster Virus. 9-11 March, 1997, Palm Beach, Florida, United States of America.

6. Pugh RNH et al. Varicella infection and pneumonia among adults. International journal of infectious diseases, 1998, 2(4):205-10.

7. Uduman SA et al. Varicella susceptibility among children and healthy adults in the
United Arab Emirates. Eastern Mediterranean health journal, 2002, 7(4/5):604-8.

8. Annual report 2002. Abu Dhabi, United Arab Emirates, Department of Preventive Medicine, Ministry of Health and Department of Population Estimates, Ministry of Planning, 2002.

9. Annual statistical report 2004. Al-Ain, United Arab Emirates, Department of Preventive Medicine Department, Ministry of Health, 2004.

10. Gershon AA, LaRussa P. Varicella-zoster virus infections. In: Katz SL, et al. eds. Krugman's infectious diseases of children, 11th ed. St Louis, Missouri, Mosby, 2004, 41:785-816.

11. Fisher RG, Edwards KM. Varicella-zoster. Pediatrics in review, 1998, 19:62-7.

12. Yawn PB, Yawn RA, Lydick E. Community impact of childhood varicella infections. Journal of pediatrics, 1997, 130 (5)759-65.

13. Choo PW et al. The epidemiology of varicella and its complications. Journal of infectious diseases, 1995, 172:706-12.

14. Pollock JI, Golding J. Social epidemiology of chickenpox in two British national

المجلة الصحية لشرق المتو سط، منظمة الصحة العالمية، المجلد الخامس عشر، العدد ع، 9 +. 
cohorts. Journal of epidemiology and community health, 1993, 47:274-81.

15. Fairley CK, Miller E. Varicella-zoster virus epidemiology: a changing scene? Journal of infectious diseases, 1996, 174(3):S314-9.

16. Law B et al. Cost of chickenpox in Canada: part 1. Cost of uncomplicated cases. Pediatrics, 1999, 104:1-6.

17. McCoy L, Sorvillo F, Simon P. Varicellarelated mortality in California, 1988-2000. Pediatric infectious disease journal, 2004, 23(6):498-503.

18. Jackson MA, Burry VF, Olson LC. Complication of varicella requiring hospitalization in previously healthy children. Pediatric infectious disease journal, 1992 11:441-5.
19. Ziebold $C$ et al. Severe complications of varicella in previously healthy children in Germany: a 1-year survey. Pediatrics, 2001, 108(5):79-84.

20. Meyer PA et al. Varicella mortality: trends before vaccine licensure in the United States, 1970-1994. Journal of infectious diseases, 2000, 182:383-90.

21. Galil K et al. Hospitalizations for varicella in the United States, 1988 to 1999. Pediatric infectious disease journal, 2002 , 21:931-5

22. Gershon AA. Varicella in mother and infants: problems old and new. In: Krugman $\mathrm{S}$, Gershon AA, eds. Infections of the fetus and newborn infant. New York, Alan Liss, 1975:75-95.

Mational Health facility survey on the quality of outpatient primary child health care services: IMCI health facility survey Morocco October-December 2007

Integrated management of childhood illness (IMCl) was introduced in Morocco in 1997 as an integrated strategy to address the most important causes of mortality and morbidity in line with the primary health care approach.

This evaluation was conducted after 7 years of IMCl expanded implementation to collect information to assess the quality of outpatient health care services provided to sick children under 5 years old at health centres with $\mathrm{IMCl}$ - trained staff.

The full document can be downloaded at:

http://www.emro.who.int/publications/Book_Details.asp?ID=973 